Biochimica et Biophysica Acta, 565 (1979) 326-346

(C) Elsevier/North-Holland Biomedical Press

BBA 99574

\title{
NUCLEAR PROTEIN KINASE ACTIVITIES DURING THE CELL CYCLE OF HeLa $S_{3}$ CELLS
}

\author{
IAN R. PHILLIPS ${ }^{a}, *$, ELIZABETH A. SHEPHARD ${ }^{a}, *$ JANET L. STEIN $^{b}$, \\ LEWIS J. KLEINSMITH ${ }^{c}$ and GARY S. STEIN ${ }^{a}$ \\ a Department of Biochemistry and Molecular Biology, University of Florida, Gainesville, \\ FL $32610 ;^{b}$ Department of Immunology and Medical Microbiology, University of Florida, \\ Gainesville, FL 32610 and $^{\mathrm{c}}$ Division of Biological Sciences, University of Michigan, Ann \\ Arbor, MI 48104 (U.S.A.)
}

(Received March 14th, 1979)

Key words: Protein kinase; Cell cycle; Phosphorylation; Histone; Non-histone protein; ( $\mathrm{HeLa} \mathrm{S}_{3}$ cell)

\section{Summary}

To ascertain the activity and substrate specificity of nuclear protein kinases during various stages of the cell cycle of HeLa $\mathrm{S}_{3}$ cells, a nuclear phosphoprotein-enriched sample was extracted from synchronised cells and assayed in vitro in the presence of homologous substrates. The nuclear protein kinases increased in activity during $S$ and $G_{2}$ phase to a level that was twice that of kinases from early $\mathbf{S}$ phase cells. The activity was reduced during mitosis but increased again in $G_{1}$ phase. When the phosphoproteins were separated into five fractions by cellulose-phosphate chromatography each fraction, though not homogenous, exhibited differences in activity. Variations in the activity of the protein kinase fractions were observed during the cell cycle, similar to those observed for the unfractionated kinases.

Sodium dodecyl sulfate polyacrylamide gel electrophoretic analysis of the proteins phosphorylated by each of the five kinase fractions demonstrated a substrate specificity. The fractions also exhibited some cell cycle stage-specific preference for substrates; kinases from $G_{1}$ cells phosphorylated mainly high molecular weight polypeptides, whereas lower molecular weight species were phosphorylated by kinases from the $S, G_{2}$ and mitotic stages of the cell cycle. Inhibition of DNA and histone synthesis by cytosine arabinoside had no effect on the activity or substrate specificity of $\mathbf{S}$ phase kinases. Some kinase fractions phosphorylated histones as well as non-histone chromosomal proteins and this phosphorylation was also cell cycle stage dependent. The presence of histones

\footnotetext{
* Present address: Department of Biochemistry, University College London, London WC1E 6BT, U.K.
} Abbreviation: SDS, sodium dodecyl sulfate. 
in the in vitro assay influenced the ability of some fractions to phosphorylate particular non-histone polypeptides; non-histone proteins also appeared to affect the in vitro phosphorylation of histones.

\section{Introduction}

There is extensive experimental evidence that suggests a role for components of the non-histone chromosomal proteins in the regulation of eukaryotic gene expression [1-10]. Many of the non-histone chromosomal proteins are phosphoproteins and modifications in their phosphate metabolism have been associated with changes in gene expression in a number of biological systems [9-13]. These modifications involve changes in the total amount of phosphorylation of the protein fraction, and alterations in the phosphorylation of specific proteins.

The composition and metabolism of non-histone chromosomal proteins has been studied during the eukaryotic cell cycle. At the level of resolution provided by one-dimensional gel electrophoresis the complement of nonhistone chromosomal proteins does not vary [14-16]. However, cell cycle stage-specific variations have been observed in the rates of synthesis, turnover and phosphorylation as well as in the accumulation of these proteins into chromatin [14,16-19], suggesting possible structural and/or regulatory roles for chromosomal protein phosphorylation.

The phosphorylation and dephosphorylation of non-histone chromosomal proteins are catalysed by nuclear protein kinases and phosphatases, respectively [11]. Several fractions containing nuclear protein kinase activity, both cyclic nucleotide dependent and independent, have been isolated from the nuclear phosphoproteins of various eukaryotic tissues and cell lines [20-24]. Recently nuclear protein kinases have been further purified from these nuclear phosphoprotein fractions by the use of casein affinity chromatography [25].

The potential importance of non-histone protein phosphorylation in the control of chromatin structure and function, and the considerable heterogeneity of the kinases that phosphorylate these proteins make it evident that these enzymes must come into consideration in any scheme that attempts to describe chromatin structure and function. Predicated on such a structural and/or regulatory role for these enzymes, one might expect to observe variations in the activities and/or substrate specificities of nuclear protein kinases associated with modifications in biological functions. Consistent with such reasoning, nuclear protein kinases have been shown to be influenced by hormones [26]. Additionally, variations in the activities of nuclear protein kinases as a total class have been observed during the $G_{1}$ and $S$ phases of the cell cycle in CHO cells using heterologous substrates, histone and casein, for assessment of enzyme activity [23].

In this study we examined protein kinases in five nuclear phosphoprotein fractions during the cell cycle of synchronised, continuously dividing HeLa $S_{3}$ cells. Levels of enzyme activity and substrate specificities were assayed using homologous histones and non-histone chromosomal proteins. Our results suggest cell cycle stage-specific variations in the activities and substrate specificities of the nuclear protein kinase fractions. 


\section{Materials and Methods}

Cell culture and cell synchronisation. Exponentially growing (log phase) $\mathrm{HeLa} \mathrm{S}_{3}$ cells were maintained in suspension culture in Joklik-modified Eagle's minimal essential medium supplemented with $7 \%$ calf serum. $\mathrm{S}$ phase cells were obtained by synchronisation with two cycles of $2 \mathrm{mM}$ thymidine block, and $\mathrm{G}_{1}$ cells were obtained $2 \mathrm{~h}$ after selective detachment of mitotic cells from semiconfluent monolayers [17].

Preparation of unfractionated nuclear protein kinases. Cells were harvested by centrifugation at $600 \times \mathrm{g}$ for $5 \mathrm{~min}$ at $37^{\circ} \mathrm{C}$. All subsequent steps were carried out at $4^{\circ} \mathrm{C}$. The cell pellet was washed three times in Earle's balanced salt solution and nuclei were isolated [27]. Examination of nuclei by light microscopy indicated an absence of significant amounts of cytoplasmic material. Nuclear pellets were homogenised in $0.14 \mathrm{M} \mathrm{NaCl}(7 \mathrm{ml} / 10 \mathrm{ml}$ of cell homogenate) and centrifuged at $7000 \times g$ for $15 \mathrm{~min}$. At this stage nuclei could be stored overnight as a frozen pellet. Nuclear protein kinases were extracted by resuspending nuclei in $1 \mathrm{M} \mathrm{NaCl}$, then reducing the salt concentration to $0.4 \mathrm{M}$ as described previously [24].

Fractionation of nuclear protein kinase activity [24]. Histones were removed from the unfractionated nuclear protein kinase sample by batch treatment with BioRex 70. A phosphoprotein-enriched fraction was then extracted by binding to calcium phosphate gel. $3 \mathrm{mg}$ of the phosphoprotein fraction were applied to a phosphocellulose column $(0.9 \times 5 \mathrm{~cm}$ Whatman $)$ that had been previously equilibrated with $0.1 \mathrm{M} \mathrm{NaCl} / 0.05 \mathrm{M}$ Tris-HCl ( $\mathrm{pH} 7.5$ ). The column was then eluted at $20 \mathrm{ml} / \mathrm{h}$ with a stepwise gradient of $10 \mathrm{ml}$ each of $0.1,0.3,0.5,0.7$ and $0.9 \mathrm{M} \mathrm{NaCl}$ (all containing $0.05 \mathrm{M}$ Tris-HCl, $\mathrm{pH} \mathrm{7.5).} \mathrm{The} \mathrm{eluant} \mathrm{was} \mathrm{col-}$ lected in $1 \mathrm{ml}$ fractions. The $A_{280}$ of each fraction was measured and the fractions constituting each protein peak were combined and dialysed overnight against $0.05 \mathrm{M}$ Tris-HCl ( $\mathrm{pH} 7.5)$.

Assessment of protein kinase activity. Protein kinase activity was assayed in a reaction mixture $(0.5 \mathrm{ml})$ that contained final concentrations of $0.05 \mathrm{M}$ Tris$\mathrm{HCl}(\mathrm{pH} 8.0) / 20 \mathrm{mM} \mathrm{MgCl} / 12 \mu \mathrm{M}\left[\gamma^{-32} \mathrm{P}\right] \mathrm{ATP}(0.5 \mathrm{Ci} / \mathrm{mmol}$ made according to Glynn and Chappell [28]). From 2 to $20 \mu \mathrm{g}$ of kinase sample were assayed. Protein concentrations were determined by the ultraviolet absorbance method of Layne [29]. When kinase fractions were assayed, $100 \mu \mathrm{g}$ of unfractionated chromosomal phosphoprotein (that had been incubated at $65^{\circ} \mathrm{C}$ for $10 \mathrm{~min}$ to inactivate endogenous kinase activity) were added as substrate. Histone kinase activity was assayed by including in the reaction mixture $60 \mu \mathrm{g}$ of heat-treated histones as substrate. The reaction mixture was incubated at $37^{\circ} \mathrm{C}$ for $10 \mathrm{~min}$. The reaction was stopped by addition of $2 \mathrm{ml}$ of ice-cold $10 \%$ trichloroacetic acid/2\% sodium pyrophosphate. Bovine serum albumin (4 mg) was added as carrier and the samples were vortexed and centrifuged at $900 \times g$ for $5 \mathrm{~min}$. Pellets were washed three times by vortexing in $10 \mathrm{ml}$ of $5 \%$ trichloroacetic acid/1\% sodium pyrophosphate. The final pellet was solubilised in $0.5 \mathrm{ml}$ NCS Tissue Solubiliser (Amersham). $3 \mathrm{ml}$ of dioxane/toluene scintillation fluid (150 ml Liquifluor/1 l toluene/1 l ethanol/1 l dioxane/240 g naphthalene) were added and the incorporation of ${ }^{32} \mathrm{P}$ into proteins was measured by liquid scintillation spectrometry. 
Polyacrylamide gel electrophoretic analysis. When samples were to be analysed by SDS-polyacrylamide gel electrophoresis, phosphorylation was carried out as described above except that $\left[\gamma_{-}{ }^{32} \mathrm{P}\right]$ ATP with specific activity of $2 \mathrm{Ci} / \mathrm{mmol}$ was used and the reaction was stopped by the addition of urea to a final concentration of $4 \mathrm{M}$. Samples were dialysed against $0.2 \%$ SDS $/ 0.01 \mathrm{M}$ sodium phosphate ( $\mathrm{pH} 7.4$ )/0.14 M 2-mercaptoethanol (150 vols.), concentrated by dialysis against the same buffer containing $30 \%$ glycerol and electrophoresed [30]. When samples were to be analysed by acetic acid/urea gel electrophoresis, the reaction was stopped by the addition of $\mathrm{H}_{2} \mathrm{SO}_{4}$ to a final concentration of $0.4 \mathrm{~N}$. Bovine serum albumin $(1 \mathrm{mg})$ was added as carrier and the samples were left at $0^{\circ} \mathrm{C}$ for $15 \mathrm{~min}$, and then centrifuged at $2500 \times \mathrm{g}$ for $5 \mathrm{~min}$. 2 vols. of cold $\left(-20^{\circ} \mathrm{C}\right)$ ethanol were added to the supernatant and histones were allowed to precipitate overnight at $-20^{\circ} \mathrm{C}$. The precipitates were pelleted by centrifugation at $6000 \times \mathrm{g}$ for $30 \mathrm{~min}$ at $4^{\circ} \mathrm{C}$. Pellets were dried under $\mathrm{N}_{2}$, dissolved in $0.9 \mathrm{M}$ acetic acid and electrophoresed [31].

SDS gels were stained with Coomassie brilliant blue and acetic acid/urea gels with amido black. Gels were scanned at $590 \mathrm{~nm}$ using a Beckman spectrophotometer with a gel-scanning attachment, then were frozen on a block of solid $\mathrm{CO}_{2}$ and sectioned transversely into $1 \mathrm{~mm}$ slices. Each slice was placed in a $5 \mathrm{ml}$ scintillation vial, dried for $2 \mathrm{~h}$ at $80^{\circ} \mathrm{C}$, and then dissolved in $200 \mu \mathrm{l}$ of $30 \%$ $\mathrm{H}_{2} \mathrm{O}_{2}$ at $80^{\circ} \mathrm{C}$ for $1.5 \mathrm{~h}$. After cooling to room temperature $3 \mathrm{ml}$ of Triton/ toluene scintillation fluid $(168 \mathrm{ml}$ Liquifluor $/ 1333 \mathrm{ml}$ Triton X-100/250 ml toluene) were added to each vial and radioactivity was assayed in a Beckman liquid scintillation spectrometer.

\section{Results}

Activity of unfractionated nuclear protein kinases throughout the cell cycle

Initially the level of total unfractionated nuclear protein kinase activity was studied throughout the cell cycle in $\mathrm{HeLa} \mathrm{S}_{3}$ cells. The cells were synchronised at the $\mathrm{G}_{1} / \mathrm{S}$ phase boundary by the double thymidine block technique, and at various stages of $S, G_{2}$ and mitosis a phosphoprotein-enriched nuclear protein fraction that contained kinase activity was extracted and assayed as described in Materials and Methods. Because of the difficulty in obtaining a synchronous population of $G_{1}$ phase cells by the thymidine block technique, they were obtained following selective mitotic detachment. As the cells progressed through $S$ phase after release from the thymidine block the nuclear protein kinase activity increased by $105 \%$ from the $G_{1} / S$ boundary to $G_{2}$ (Fig. 1). During this period the protein content of the $0.4 \mathrm{M} \mathrm{NaCl}$ nuclear fraction increased by only $22 \%$ (not shown). Thus, the increase in kinase activity was not merely a response to an increased level of substrate. By mitosis $(9 \mathrm{~h}$ after release from thymidine block), the activity had decreased almost to the level at the $G_{1} / S$ phase boundary. The level of nuclear protein kinase activity of cells harvested $2 \mathrm{~h}$ after mitotic detachment $\left(G_{1}\right)$ was similar to that of $G_{2}$ phase cells. When cells synchronised by selective mitotic detachment were allowed to traverse $G_{1}$ and $S$ phase, an increase in kinase activity similar to that observed when cells were synchronised by double thymidine block was seen during late $S$ phase (Fig. 1). This result suggests that the increase in kinase activity during 


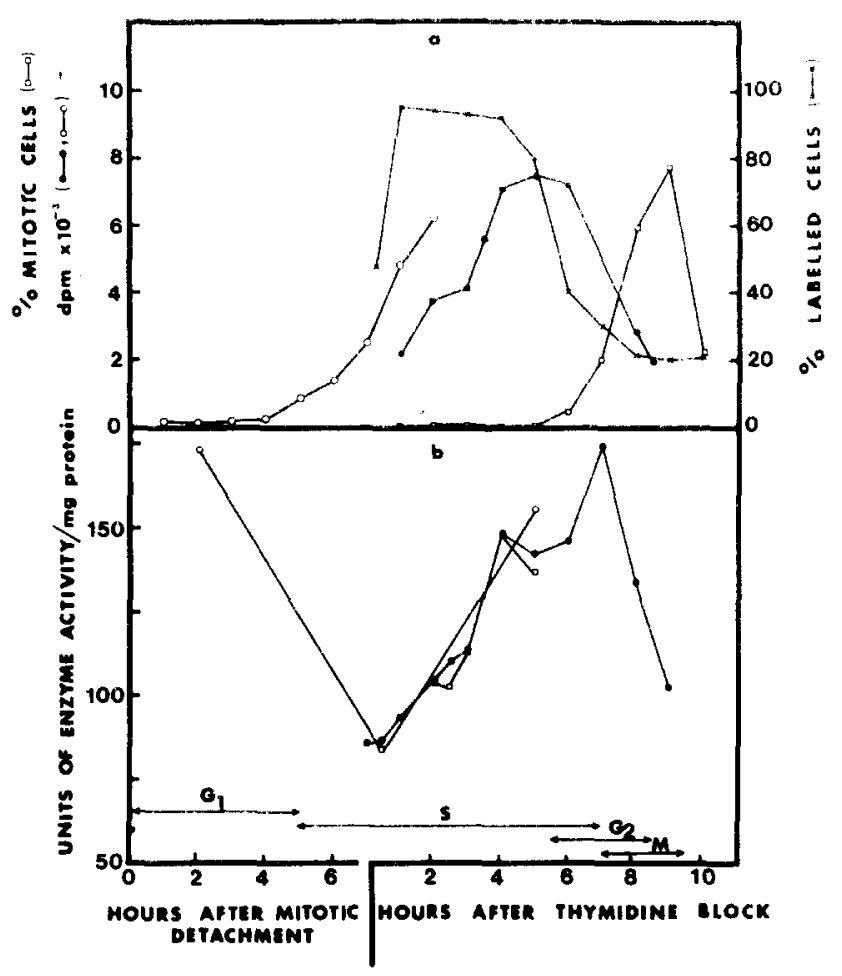

Fig. 1. Nuclear protein kinase activity throughout the cell cycle of HeLa $\mathrm{S}_{3}$ cells. (a) Monitoring cell cyle stages. Incorporation of $\left[2^{-14} \mathrm{C}\right]$ thymidine into DNA at various times after selective detachment of mitotic cells (O), and after release from a double $2 \mathrm{mM}$ thymidine block $(\bullet) ; 10^{6}$ cells were labelled for $30 \mathrm{~min}$ with $0.2 \mu \mathrm{Ci}$ of $\left[2-{ }^{14} \mathrm{C}\right]$ thymidine, and the amount of radioactivity incorporated into cold $20 \%$ trichloroacetic acid-precipitable material was determined. Percentage of cells in DNA synthesis $(X)$ or having a mitotic index $(0)$ at various times after release of cells from two cycles of $2 \mathrm{mM}$ thymidine block. Cells were labelled with $5 \mu \mathrm{Ci}$ of $\left[{ }^{3} \mathrm{H}\right]$ thymidine $/ \mathrm{ml}$ for $15 \mathrm{~min}$, and the percentage of cells in DNA synthesis was determined autoradiographically. The mitotic index was determined from the autoradiographic preparations. (b) Nuclear protein kinase activity was extracted and assayed, as described in Materials and Methods, from cells at various times after selective mitotic detachment $(O)$, or release from two cycles of $2 \mathrm{mM}$ thymidine block $(\bullet) . \square, 2 \mathrm{~h}$ after release from thymidine block, cytosine arabinoside $(40 \mu \mathrm{g} / \mathrm{ml}) \mathrm{was}$ added to cells and nuclear protein kinase activity was assayed at various times.

$\mathrm{S}$ and $\mathrm{G}_{2}$ phase was due to the passage of cells through the cell cycle and was not merely an artifact resulting from thymidine synchronisation. Thus, nuclear protein kinase activity varied during the cell cycle with peaks in $G_{1}$ and $G_{2}$ and decreased activity during early $\mathrm{S}$ and mitosis.

The relationship between nuclear protein kinase activity and DNA replication was examined by comparing the kinase activity of normal $\mathbf{S}$ phase cells with that of $\mathbf{S}$ phase cells that had been treated with cytosine arabinoside $(40 \mu \mathrm{g} / \mathrm{ml})$. This drug concentration inhibits DNA and histone synthesis by 98 and 99\%, respectively [32]. As shown in Fig. 1, inhibition of DNA and histone synthesis by cytosine arabinoside did not significantly influence the enhanced level of nuclear protein kinase activity observed during late $S$ and $G_{2}$ phases. It therefore appears that this increase in nuclear protein kinase activity is not dependent on concomitant DNA or histone synthesis. 


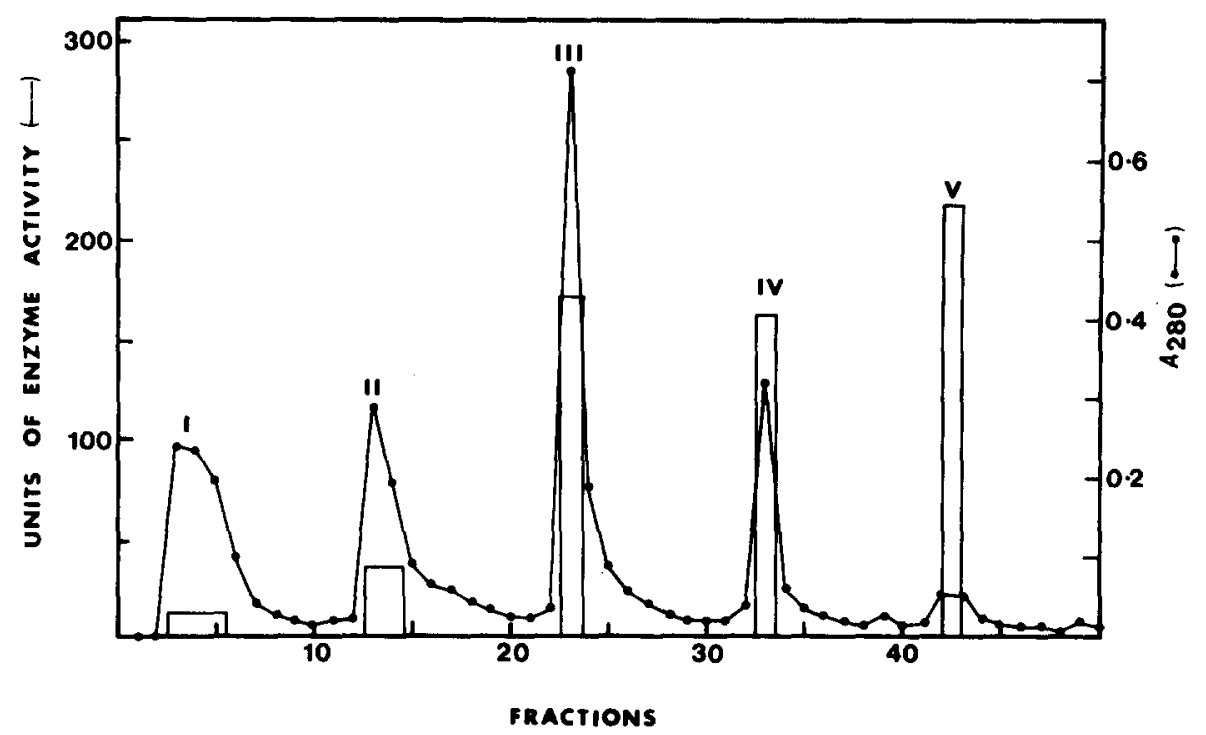

Fig. 2. Phosphocellulose chromatography of the phosphoprotein-enriched fraction of chromosomal proteins from log phase HeLa cells. The chromosomal phosphoprotein fraction was prepared as described in Materials and Methods and dialysed overnight against $0.05 \mathrm{M}$ Tris- $\mathrm{HCl}$ (pH 7.5), $0.1 \mathrm{M} \mathrm{NaCl}$. The dialysed solution was applied to a phosphocellulose column $(0.9 \times 5 \mathrm{~cm})$ that had been pre-equilibrated with $0.1 \mathrm{M} \mathrm{NaCl}, 0.05 \mathrm{M}$ Tris-HCl (pH 7.5). Protein was eluted with a step-wise gradient of $10 \mathrm{ml}$ each of $0.1,0.3,0.5,0.7$ and $0.9 \mathrm{M} \mathrm{NaCl}$. Fractions of approximately $1 \mathrm{ml}$ were collected. Fractions under each protein peak were pooled, dialysed overnight against $0.05 \mathrm{M}$ Tris- $\mathrm{HCl}(\mathrm{pH} 7.5)$ and assayed for protein content and kinase activity.

Fractionated nuclear protein kinase activities during the cell cycle

To examine in more detail the cell cycle variations of the kinases, and in particular the relationship between kinase activity and DNA synthesis, we fractionated the chromosomal phosphoproteins by phosphocellulose chromatography into five groups (Fig. 2) as described in Materials and Methods. Peaks I-V represented $2,6,29,27$ and $36 \%$, respectively, of the recovered kinase activity and the activities (in pmol phosphate incorporated $\cdot \mathrm{mg}^{-1} \cdot \mathrm{min}^{-1}$ ) of these fractions were $47,81,276,707$ and 3000 , respectively. These five groups of proteins are henceforth referred to as 'kinase fractions' $\mathrm{I}-\mathrm{V}$.

Comparison of fractionated nuclear protein kinase activities during the cell cycle. The activities of the nuclear protein kinase fractions were examined at various stages of the cell cycle to determine whether all fractions would reflect the variation in the activity of the unfractionated kinases (Fig. 1). On the basis of results obtained from studies of unfractionated kinases (Fig. 1), four representative cell cycle time points were selected for more detailed examination. These were a point in $G_{1}(2 \mathrm{~h}$ after selective mitotic detachment); a point in early $\mathrm{S}$ phase ( $2 \mathrm{~h}$ after release from thymidine block) corresponding to the low level of kinase activity during this stage of the cell cycle; the $S / G_{2}$ boundary ( $6 \mathrm{~h}$ after release from thymidine block) corresponding to a point near the peak of kinase activity in $\mathrm{G}_{2}$; and mitosis $(9 \mathrm{~h}$ after release from thymidine block), corresponding to a low level of kinase activity. Cells were harvested at these points of the cell cycle and nuclear proteins were separated into the five 


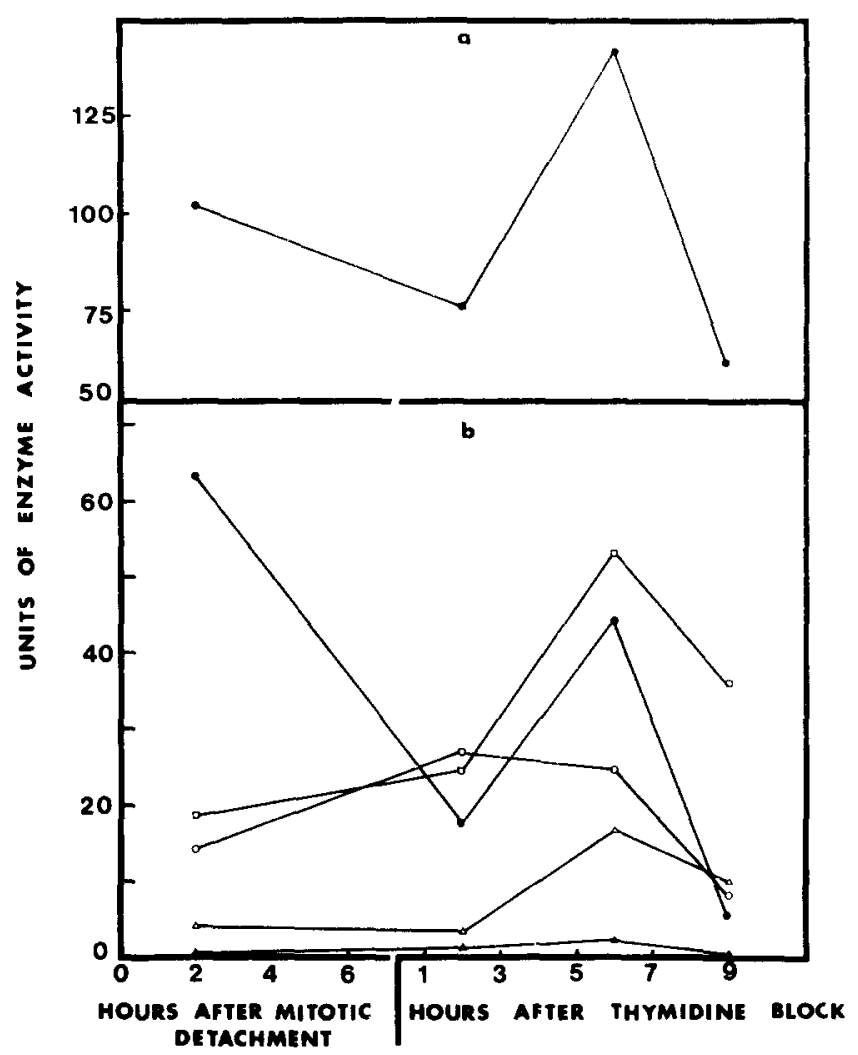

Fig. 3. Cell cycle variation in the kinase activities (pmol phosphate incorporated $\cdot \min ^{-1}$ ) of the five fractions obtained by phosphocellulose chromatography. Cells were harvested $2 \mathrm{~h}$ after selective mitotic detachment, and 2,6 and $9 \mathrm{~h}$ after release from thymiciue block. The chromosomal phosphoprotein fraction was isolated from each batch of cells and separated into five fractions by phosphocellulose chromatography as described in Materials and Methods. Each fraction was assayed for kinase activity. (a) •, sum of the activities of all five fractions. (b) 4 , kinase activity of fraction $I$; $\Delta$, kinase activity of fraction II; $\square$, kinase activity of fraction III; $O$, kinase activity of fraction IV; $\bullet$, kinase activity of fraction $V$.

kinase fractions as described in Materials and Methods.

Because each protein kinase fraction may have contained some non-kinase proteins in addition to several kinases, the activity (expressed in enzyme units/ mg protein) could have changed in response to a cell cycle stage-specific variation in the amount of a co-fractionating non-kinase protein. In order to overcome this difficulty, the activities of the kinase fractions were expressed in units of enzyme activity recovered per fraction (Fig. 3 ). The cell cycle profile of enzyme activity units differed for each nuclear protein kinase fraction (Fig. 3). However, all fractions (except IV) increased their activity during the transition from early $S$ phase to the $S / G_{2}$ boundary. This increase ranged from $50 \%$ for fraction I to $360 \%$ for fraction II. Fractions I-III had their highest activity at the $S / G_{2}$ boundary, whereas the activity of fraction $V$ was highest during $G_{1}\left(42 \%\right.$ more than its activity at the $S / G_{2}$ boundary). The proportion of the total nuclear protein kinase activity represented by a particular kinase fraction varied during the cell cycle. For example, during $G_{1}$, fraction $V$ 
TABLE I

EFFECT OF INHIBITION OF DNA AND HISTONE SYNTHESIS ON NUCLEAR PROTEIN KINASE FRACTIONS FROM S PHASE HeLa $S_{3}$ CELLS

Cells were synchronised by a double thymidine block. Cytosine arabinoside $(40 \mu \mathrm{g} / \mathrm{ml}) \mathrm{was}$ added to the cells $2 \mathrm{~h}$ after release from the block (treated cells). Control cells were not treated with cytosine arabinoside. Mid S phase and late $S$ phase cells were harvested 3.5 and $6 \mathrm{~h}$, respectively, after release from the block. Nuclear protein kinase fractions were prepared and assayed as described in Materials and Methods.

\begin{tabular}{|c|c|c|c|c|}
\hline \multirow[t]{3}{*}{ Nuclear protein kinase fraction } & \multicolumn{4}{|c|}{$\begin{array}{l}\text { Nuclear protein kinase activity } \\
\text { (pmol of phosphate incorporated } \cdot \mathrm{mg}^{-1} \cdot \mathrm{min}^{-1} \text { ) }\end{array}$} \\
\hline & \multicolumn{2}{|c|}{ Mid S phase } & \multicolumn{2}{|c|}{ Late S phase } \\
\hline & Control & Treated & Control & Treated \\
\hline 1 & 4 & $\mathbf{5}$ & 47 & 52 \\
\hline II & 10 & 11 & 81 & 90 \\
\hline III & 25 & 37 & 276 & 208 \\
\hline IV & 1015 & 1309 & 707 & 781 \\
\hline $\mathbf{v}$ & - & - & 2954 & 3549 \\
\hline
\end{tabular}

accounted for over $60 \%$ of all the kinase activity, whereas in mitosis it represented less than $10 \%$ of the total activity. The activities of all the kinase fractions decreased from the $\mathbf{S} / \mathbf{G}_{2}$ boundary to mitosis, and this corresponds to results obtained using unfractionated kinases (Fig. 1).

Effects of cytosine arabinoside on fractionated kinase activities during $S$ phase. As shown in Fig. 1, cytosine arabinoside treatment of $S$ phase cells had no significant effect on unfractionated nuclear protein kinase activity. However, the treatment may have preferentially affected some of the kinases contained in the heterogeneous sample. The activities of the five kinase fractions isolated from cytosine arabinoside-treated and untreated cells were therefore compared (Table I). Cytosine arabinoside $(40 \mu \mathrm{g} / \mathrm{ml})$ was added to $\mathrm{S}$ phase cells $2 \mathrm{~h}$ after thymidine synchronisation and cells were harvested either $3.5 \mathrm{~h}$ (mid $\mathrm{S}$ phase) or $6 \mathrm{~h}$ (late $\mathrm{S}$ phase) after release from the thymidine block. These times corresponded to points at which the kinase activity had started to increase, and at which it had almost reached maximum activity, respectively (Fig. 1). Similar to the findings for the unfractionated kinases, the activities of the kinase fractions were not significantly affected by the inhibition of DNA and histone synthesis.

The effect of histones on the activity of nuclear protein kinase fractions at various stages of the cell cycle. To determine whether any of of the protein fractions contained histone as well as non-histone protein kinases, they were assayed using a mixture of histones and non-histones as substrates. The presence of histones in the assay had different effects on the overall activity of each kinase fraction and these effects varied during the cell cycle (Table II). In $\mathrm{G}_{1}$ phase, the activity of all the kinase fractions decreased in the presence of histones. During $\mathbf{S}$ phase, histones increased the activity of fraction $\mathrm{V}$ while decreasing the activity of fraction II. In mitosis, all the fractions (particularly I, II and V) increased their activity in the presence of histone.

A histone-mediated increase in the activity of a protein kinase fraction could 
TABLE II

EFFECT OF HISTONES ON THE ACTIVITY OF NUCLEAR PROTEIN KINASE FRACTIONS FROM VARIOUS CELL CYCLE STAGES

Activity of nuclear protein kinase fractions with non-histones and histones as substrate (as a percentage of the activity observed when non-histones alone were used as substrate). $G_{1}$ phase cells were harvested $2 \mathrm{~h}$ after selective detachment of mitotic cells. Early phase $\mathbf{S}, \mathbf{S} / \mathbf{G}_{2}$ phase and mitotic cells were harvested 2,6 and $9 \mathrm{~h}$, respectively, after release from two cycles of $2 \mathrm{mM}$ thymidine block. Kinase fractions were extracted as described in Materials and Methods and assayed in the presence of a mixture of non-histones and histones, or non-histones alone.

\begin{tabular}{lcrrr}
\hline Kinase fraction & $\mathrm{G}_{1}$ & Early $S$ & $\mathrm{~S} / \mathrm{G}_{2}$ & Mitosis \\
\hline I & 59 & 100 & 109 & 300 \\
II & 52 & 61 & 62 & 210 \\
III & 39 & 97 & 80 & 110 \\
IV & 36 & 108 & 109 & 106 \\
V & 38 & 191 & 124 & 209 \\
\hline
\end{tabular}

result from (i) activation of a histone kinase in the fraction, or (ii) histone stimulation of a non-histone kinase [33,34]. To distinguish between these possibilities, the phosphorylated proteins were analysed by SDS-polyacrylamide gel electrophoresis (see below).

Phosphorylation of defined molecular weight classes of chromosomal proteins by nuclear protein kinases from various stages of the cell cycle

Assaying nuclear protein kinase activity alone does not provide information concerning the number or diversity of the proteins that are phosphorylated. In order to obtain such information the phosphorylated proteins were analysed by SDS-polyacrylamide gel electrophoresis as described in Materials and Methods.

Proteins phosphorylated by unfractionated nuclear protein kinases. The specific activity of nuclear protein kinases was found to vary during the cell cycle (Fig. 1). In order to determine whether this variation represented a uniform change in enzyme activity towards all substrate proteins or cell cyclespecific changes in substrate specificity the complement of proteins phosphorylated by unfractionated kinases isolated from different stages of the cell cycle were compared (Fig. 4).

The only polypeptide molecular weight class that was highly phosphorylated by unfractionated kinases isolated from each stage of the cell cycle was D $\left(M_{\mathrm{r}}\right.$ 105000 ) (Fig. 4). However, kinases from $G_{1}$ phase cells phosphorylated this class of chromosomal polypeptides to a much greater extent than did kinases from the other stages of the cell cycle. In fact, most of the phosphate incorporated into proteins by $G_{1}$ phase kinases was found in $D$. Kinases from early $\mathrm{S}, \mathrm{S} / \mathrm{G}_{2}$ and mitosis all phosphorylated low molecular weight polypeptides in I $\left(M_{\mathrm{r}} 23000\right)$, but only kinases from $\mathrm{S} / \mathrm{G}_{2}$ phosphorylated polypeptides in $\mathrm{H}$ $\left(M_{\mathrm{r}} 26000\right)$ to a significant extent (Fig. 4). Thus, although there is some overlap of polypeptide molecular weight classes phosphorylated by kinases from different cell cycle stages, kinases from no two stages phosphorylate the same set of polypeptides.

The increase in kinase activity from early $S$ phase to the $S / G_{2}$ boundary 


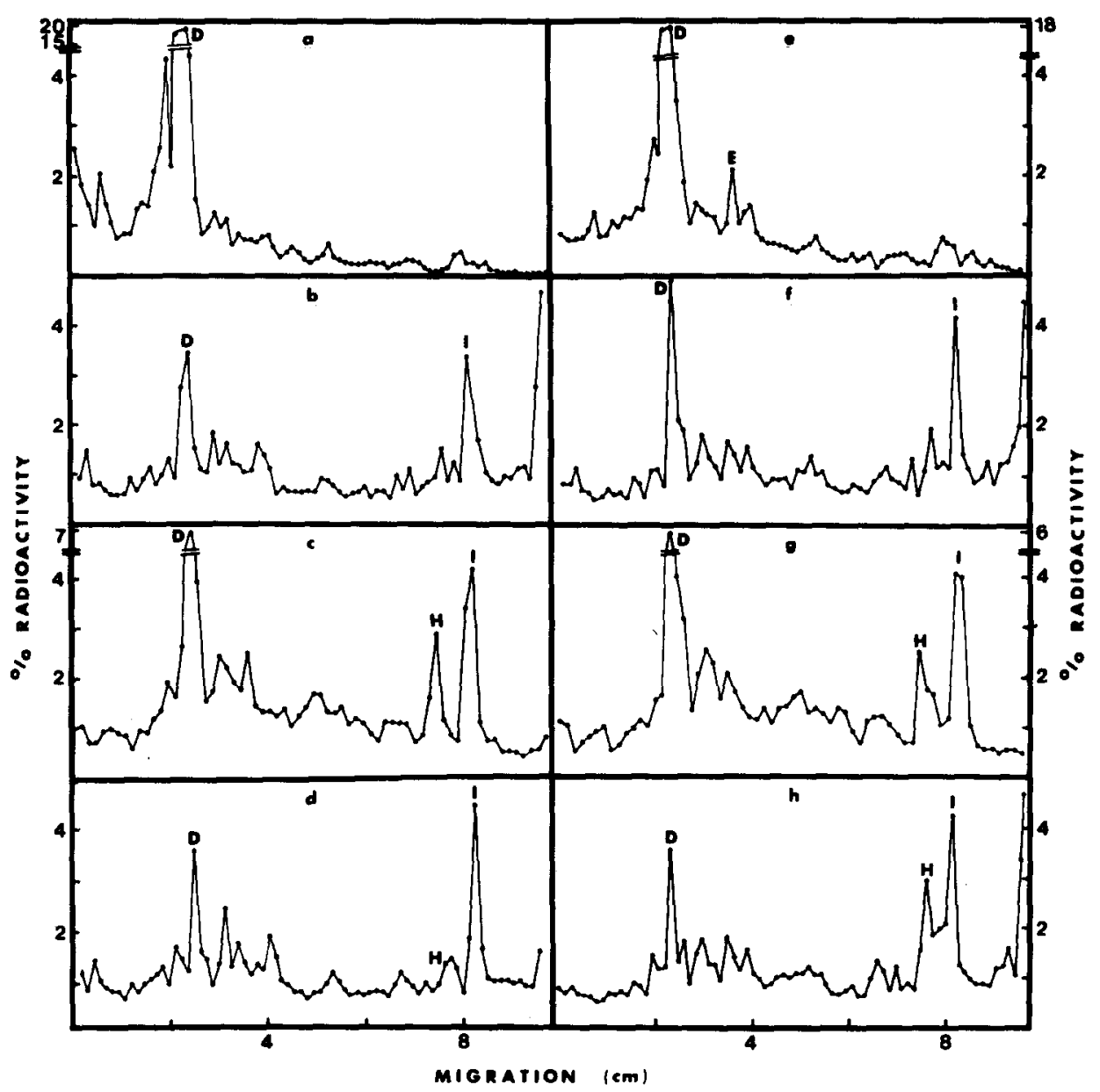

Fig. 4. Distribution of ${ }^{32} \mathrm{P}$ in chromosomal proteins phosphorylated by unfractionated nuclear protein kinases isolated from different stages of the cell cycle. Unfractionated nuclear protein kinases were isolated from various cell cycle stages and used to phosphorylate homologous non-histone chromosomal proteins (a-d) or homologous non-histone and histone proteins $(e-h)$. After phosphorylation the substrate proteins were electrophoresed on SDS-polyacrylamide gels. Molecular weight markers were run in parallel wells. Gels were sectioned transversely into $1 \mathrm{~mm}$ slices and the radioactivity in each slice was determined by liquid scintillation spectrometry (Materials and Methods). Radioactivity in slices was plotted as a percentage of the total radioactivity in a gel. Proteins phosphorylated by unfractionated kinases extracted from: (a and e) $G_{1}$ phase cells; ( $b$ and $f$ ) early $S$ phase cells; (c and $g$ ) $S / G_{2}$ phase cells; (d and $n$ ) mitotic cells.

(Fig. 1) may correspond, at least in part, to the initiation of phosphorylation of polypeptides in molecular weight class $H$ by $S / G_{2}$ kinases (Fig. 4). Conversely, the subsequent decrease in kinase activity from the $S / G_{2}$ boundary to mitosis may be due, in part, to the decrease in phosphorylation of polypeptides in $\mathrm{H}$ by kinases in mitotic cells. The increase of kinase activity as cells progress from mitosis into $G_{1}$, and the subsequent decrease in this activity in early $S$ phase may be due to changes in the phosphorylation of polypeptides in molecular weight class $\mathrm{D}$. 
Proteins phosphorylated by nuclear protein kinase fractions. To examine the cell cycle substrate specificity of the various kinase fractions, the complement of proteins phosphorylated by kinase fractions isolated from different stages of the cell cycle were compared. Nuclear protein kinase fractions were isolated from $G_{1}$, early $S, S / G_{2}$, and mitotic phases of the cell cycle of HeLa $S_{3}$ cells and used to phosphorylate exogenously added, heat-inactivated, homologous chromosomal proteins. The phosphoprotein fraction used as substrate for the kinase fractions was extremely heterogeneous and comprised $15 \%$ of the total non-histone chromosomal proteins.

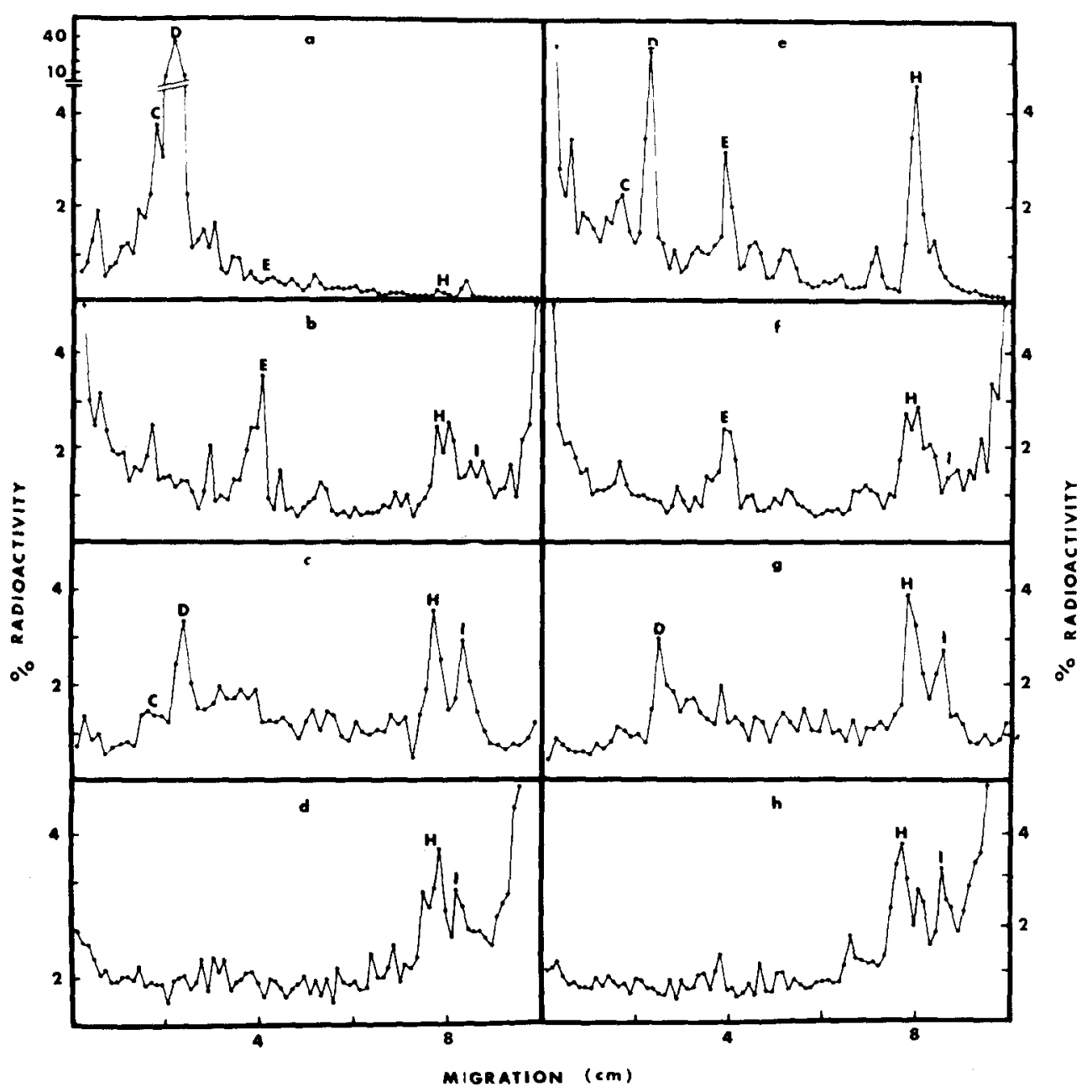

Fig. 5. Distribution of $32 \mathrm{P}$ in chromosomal proteins phosphorylated by kinase fraction II extracted from various stages of the cell cycle. Non-histone chromosomal proteins $(a-d)$ or non-histone and histone proteins $(e-h)$ were phosphorylated in the presence of $[\gamma-32$ P $]$ ATP by kinase fraction II extracted from various cell cycle stages. The phosphorylated proteins were analysed on SDS-polyacrylamide gels. Procedures were performed as described in Materials and Methods and in Fig. 4. Proteins phosphorylated by kinase fraction II from: (a and e) $G_{1}$ phase cells; (b and $f$ ) early $S$ phase cells; (c and g) $S / G_{2}$ phase cells; (d and h) mitotic cells. 
Kinase fraction II isolated from $\mathrm{G}_{1}$ cells phosphorylated mainly the high molecular weight protein classes $\mathrm{B}, \mathrm{C}$ and $\mathrm{D}\left(M_{\mathrm{r}} 125000,115000\right.$ and 105000 , respectively) (Fig. 5). However, the proportion of phosphate incorporated into these polypeptide classes differed when kinase fraction II from other stages of the cell cycle was employed. The level of phosphorylation of B was relatively lower in all other phases of the cell cycle, $\mathrm{C}$ remained high in early $S$ but declined at $S / G_{2}$ and mitosis, whereas $D$ decreased to an intermediate level during $\mathrm{S}$ phase then fell still further during mitosis. Phosphorylation of polypeptides in $E\left(M_{\mathrm{r}} 72000\right)$ was relatively high in early $\mathrm{S}$ and mitosis, and phosphorylation of polypeptides in $\mathrm{G}\left(M_{\mathrm{r}} 35000\right)$ increased steadily from $\mathrm{G}_{1}$ to mitosis. Chromosomal polypeptides $\mathrm{H}\left(M_{\mathrm{r}} 26000\right)$ and $\mathrm{I}\left(M_{\mathrm{r}}\right.$ 23000 ) were appreciably phosphorylated only by kinase fraction II from $\mathrm{S} / \mathrm{G}_{2}$ cells.

One of the major classes of chromosomal polypeptides phosphorylated by kinase fraction III from all phases of the cell cycle was A $\left(M_{\mathrm{r}} 160000\right)$ (Fig. 6). Although polypeptides in molecular weight class C ( $\left.M_{\mathrm{r}} 115000\right)$ were also phosphorylated by kinase fraction III from all cell cycle phases, the kinase fraction from $G_{1}$ cells phosphorylated them to a much greater extent. Polypeptides in $E$ and $G$ were phosphorylated by kinases from all stages of the cell cycle but phosphorylation of $\mathbf{G}$ was more pronounced in early $\mathbf{S}$ and mitosis. Polypeptides in $F\left(M_{\mathrm{r}} 42000\right)$ were phosphorylated by kinases from all stages of the cell cycle except $S / G_{2}$. Polypeptides in $H$ and $I$ were phosphorylated to an appreciable extent only by kinase from $S / G_{2}$.

Polypeptides contained in $\mathrm{C}$ and $\mathrm{D}$ accounted for about two-thirds of the total phosphate incorporated into proteins by kinase fraction IV from $G_{1}$ cells, however, kinase fraction IV from other stages of the cell cycle phosphorylated these proteins to a much lower level (Fig. 7). Phosphorylation of polypeptides in $\mathrm{E}$ was pronounced in early $\mathrm{S}$ phase, and phosphorylation of low molecular weight classes of chromosomal polypeptides ( $\mathrm{H}$ and $\mathrm{I}$ ) was prominent in early $\mathrm{S}, \mathrm{S} / \mathrm{G}_{2}$ and mitosis. As was the case with kinase fraction IV, polypeptide classes $\mathrm{C}$ and $\mathrm{D}$ accounted for the majority of the total phosphate incorporated into proteins by kinase fraction $V$ from $G_{1}$ cells (not shown), and $S / G_{2}$ was the only other stage where polypeptides in $\mathrm{D}$ were phosphorylated. Polypeptides in I were phosphorylated by kinase fraction $V$ from early $S, S / G_{2}$ and mitosis, but polypeptides in $\mathrm{H}$ were phosphorylated only by kinase fraction $\mathrm{V}$ from $\mathrm{S} / \mathrm{G}_{2}$ cells.

The protein phosphorylation profiles mediated by unfractionationated nuclear protein kinases from different stages of the cell cycle (Fig. 4) corresponded quite well to the sum of the phosphorylation profiles produced by the kinease fractions (Figs. 5-7). Thus, kinases from $G_{1}$ cells phosphorylated predominantly polypeptide classes $C$ and $D$, and $S / G_{2}$ kinases phosphorylated mainly polypeptide classes $\mathrm{D}, \mathrm{H}$ and $\mathrm{I}$.

Another question that we can address is whether particular polypeptide molecular weight classes were phosphorylated by a specific kinase fraction. From Figs. 5-7 it can be seen that some polypeptides in molecular weight classes, such as $\mathrm{C}$ and $\mathrm{D}$, were phosphorylated by all the kinases fractions. However, there were other polypeptide molecular weight classes that were phosphorylated by only one or two of the kinase fractions, for example, poly- 


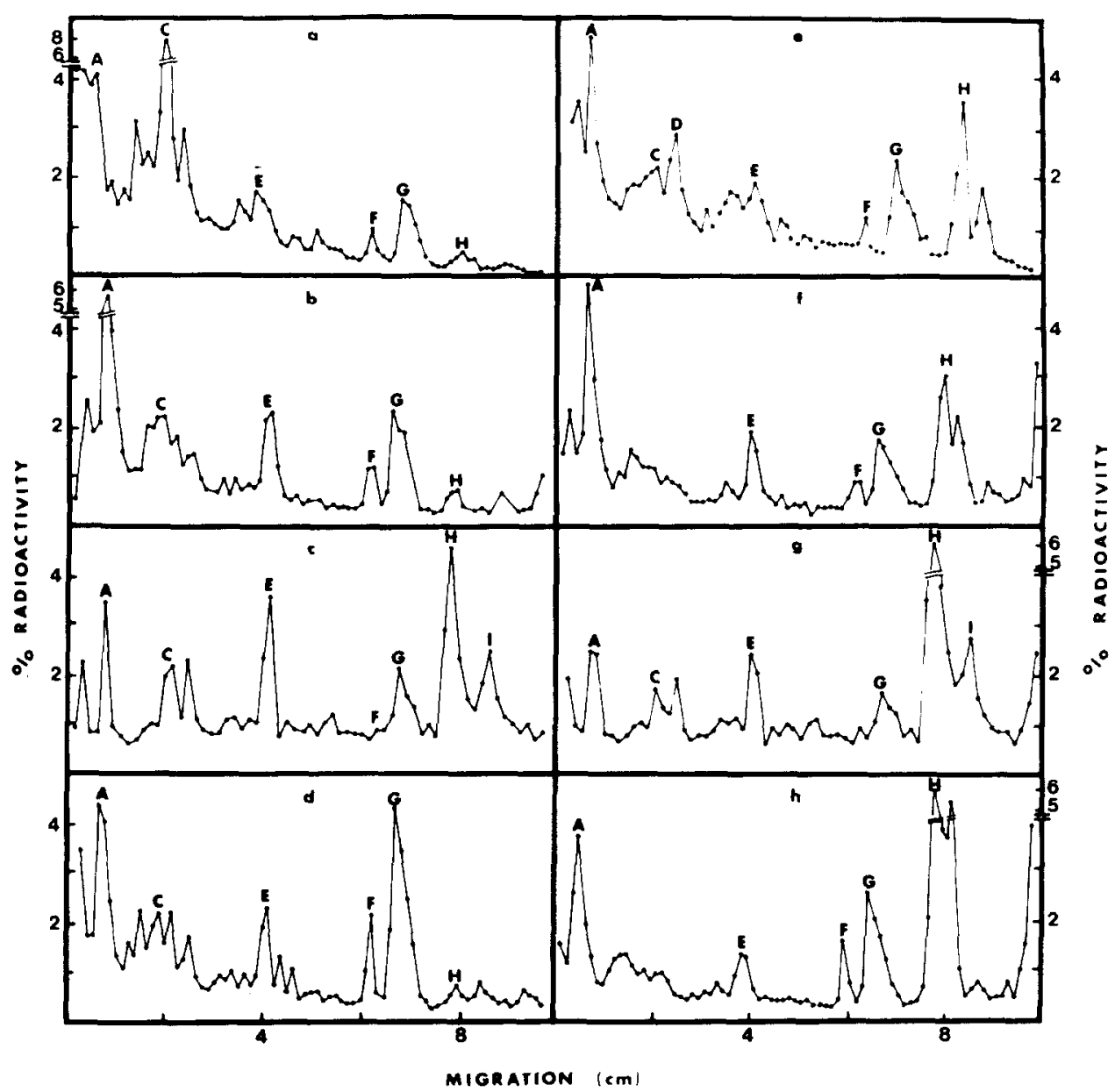

Fig. 6. Distribution of ${ }^{32} \mathrm{P}$ in chromosomal proteins phosphorylated by kinase fraction III extracted from various stages of the cell cycle. Non-histone chromosomal proteins (a-d) or non-histone and histone proteins $(e-h)$ were phosphorylated by kinase fraction III extracted from: (a and e) $G_{1}$ phase cells; (b and $f$ ) early $S$ phase cells; ( $c$ and $g$ ) $S / G_{2}$ phase cells; ( $d$ and $h$ ) mitotic cells. Phosphorylated proteins were analysed by SDS-polyacrylamide gel electrophoresis. Procedures were performed as described in Materials and Methods and Fig. 4.

peptides in A were phosphorylated mainly by kinase fraction III (Fig. 6), polypeptides in $\mathrm{G}$ by kinase fractions II and III (Figs. 5 and 6), and polypeptides in I mainly by kinase fractions IV and V (Fig. 7).

The effect of inhibition of DNA synthesis on the complement of nuclear proteins phosphorylated by $S$ phase nuclear protein kinase fractions. Inhibition of DNA synthesis was found to have no effect on the activity of unfractionated (Fig. 1) or fractionated nuclear protein kinases (Table I); however, these results do not preclude the possibility that the complement of proteins phosphorylated was changed by the inhibition of DNA synthesis. This possibility was examined by electrophoretically comparing the proteins phosphorylated by kinase fractions extracted from cytosine arabinoside-treated and untreated 
cells. Cytosine arabinoside treatment had no specific effects on the phosphorylation of any of the various molecular weight classes of chromosomal polypeptides (not shown). Thus, when DNA synthesis was inhibited, none of the kinase fractions changed the complement of proteins that it phosphorylated.

Effects of histones on the phosphorylation of chromosomal proteins by fractionated nuclear protein kinases throughout the cell cycle. When unfractionated HeLa histones (H1, H2A, H2B, H3 and H4) (together with HeLa nonhistone chromosomal phosphoproteins) were used as substrate, the activity of most of the HeLa nuclear protein kinase fractions was altered (Table II). To ascertain if this change in kinase activity was due to the phosphorylation of histones or to histone-mediated changes in the phosphorylation of non-histone proteins, the kinase-induced phosphorylation of chromosomal protein substrate was examined by SDS-polyacrylamide gel electrophoresis. In the presence of histones, only nuclear protein kinase fraction II changes its pattern of chromosomal protein phosphorylation during all stages of the cell cycle, increasing the level of phosphorylation of polypeptides contained in peak H (Fig. 5). Although peak $\mathrm{H}$ corresponds to the region of the SDS-polyacrylamide gel where histone $\mathrm{H} 1$ migrates, the possibility must be considered that the phosphorylated chromosomal polypeptides contained in peak $\mathrm{H}$ may in part be nonhistone proteins that co-electrophorese with $\mathrm{H} 1$ histone in this gel system. To address this possibility, after in vitro phosphorylation, histones were acid extracted and electrophoresed on acetic acid/urea polyacrylamide gels as described in Materials and Methods. When non-histone proteins alone were used as substrate for kinase fraction II, phosphorylated chromosomal polypeptides did not electrophorese in the $\mathrm{H} 1$ region of the gels, whereas when histones were a component of the substrate, a highly phosphorylated chromosomal polypeptide co-electrophoresed with $\mathrm{H} 1$ histone (not shown). Therefore, the increased phosphorylation observed when histones were used as substrate for kinase fraction II was probably due in part to phosphorylation of histone H1. This apparent phosphorylation of histone $\mathrm{H} 1$ by kinase fraction II was most pronounced during mitosis, when almost 50\% of the incorporated phosphate was attached to $\mathrm{H} 1$ histone (Fig. 5). The preferential phosphorylation of $\mathrm{H} 1$ histone by kinases from mitotic cells was also observed when proteins were phosphorylated with unfractionated kinases (Fig. 4h). During $\mathrm{G}_{1}$ and early $\mathrm{S}$ phase one of the major phosphorylated proteins (C, $\left.M_{\mathrm{r}} 115000\right)$ exhibited a preferential decline in its level of phosphorylation in the presence of histones (Fig. 5).

In most stages of the cell cycle only one or two kinase fractions phosphorylated histones in the presence of non-histone proteins, for example, fraction II in $S / G_{2}$ and fractions II and III in early $S$ phase and mitosis (Figs. 5 and 6 ), but during $G_{1}$ kinase fractions II $-V$ all phosphorylated histones in the presence of non-histone proteins (Figs. 5-7). In the presence of histones, $G_{1}$ kinase fractions IV and V not only phosphorylated histones but also increased the phosphorylation of a middle molecular weight range non-histone protein, $\mathrm{E}\left(M_{\mathrm{r}}\right.$ 72 000) (Fig. 7).

Thus, although the presence of histones (in addition to non-histone chromosomal phosphoproteins) caused a decrease in the activity of $G_{1}$ phase kinases (Table II), gel electrophoretic analysis of the phosphorylated polypeptides 


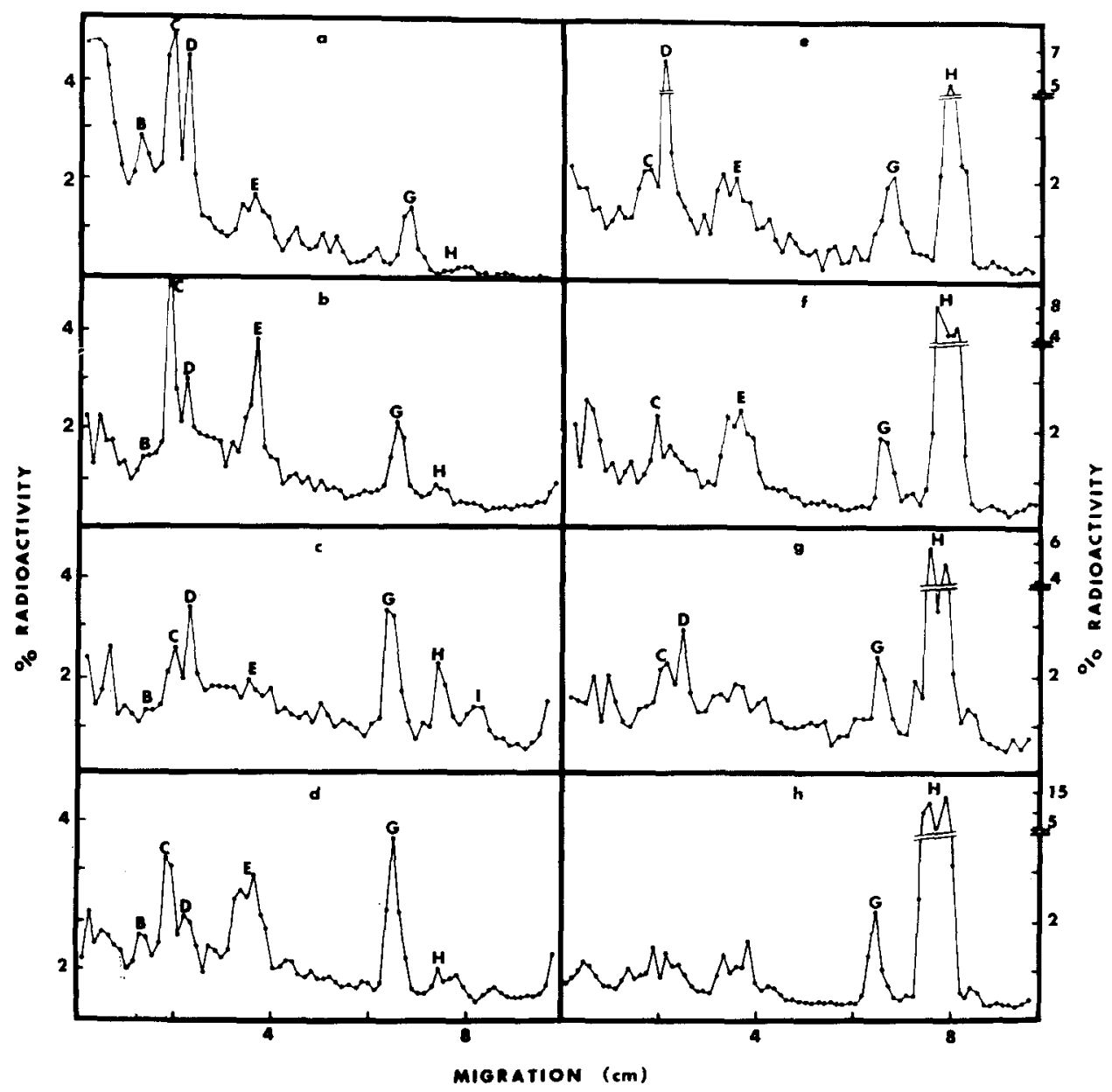

Fig. 7. Distribution of $3.2 \mathrm{P}$ in chromosomal proteins phosphorylated by kinase fraction IV extracted from various stages of the cell cycle. Non-histone chromosomal proteins (a-d) or non-histone and histone proteins $(e-h)$ were phosphorylated by kinase fraction IV extracted from: (a and e) $G_{1}$ phase cells; ( $b$ and $f$ ) early $S$ phase cells; ( $c$ and $g$ ) $S / G_{2}$ phase cells; ( $d$ and $h$ ) mitotic cells. Phosphorylated proteins were analysed by SDS-polyacrylamide gel electrophoresis. Procedures were performed as described in Materials and Methods and Fig. 4. The distribution of $32 \mathrm{P}$ in chromosomal proteins phosphorylated by kinase fraction $\mathrm{V}$ extracted from various stages of the cell cycle was similar to that in proteins phosphorylated by kinase fraction IV.

(Figs. 5-7) showed that histones probably were phosphorylated by these kinases. The reduction in kinase activity in the presence of histones may be correlated with the decrease in the amount of phosphate incorporated into the high molecular weight polypeptide classes $\mathrm{C}$ and $\mathrm{D}$.

Phosphorylation of histones by $S$ phase nuclear protein kinases in the absence of non-histone chromosomal proteins. When histones were used as substrate for the $S$ phase kinases in the presence of non-histone chromosomal proteins, only kinase fractions II and III phosphorylated histones. However, when histones alone were used as substrate, and the phosphorylated proteins were analysed on acetic acid/urea polyacrylamide gels (Fig. 8), kinase fractions 


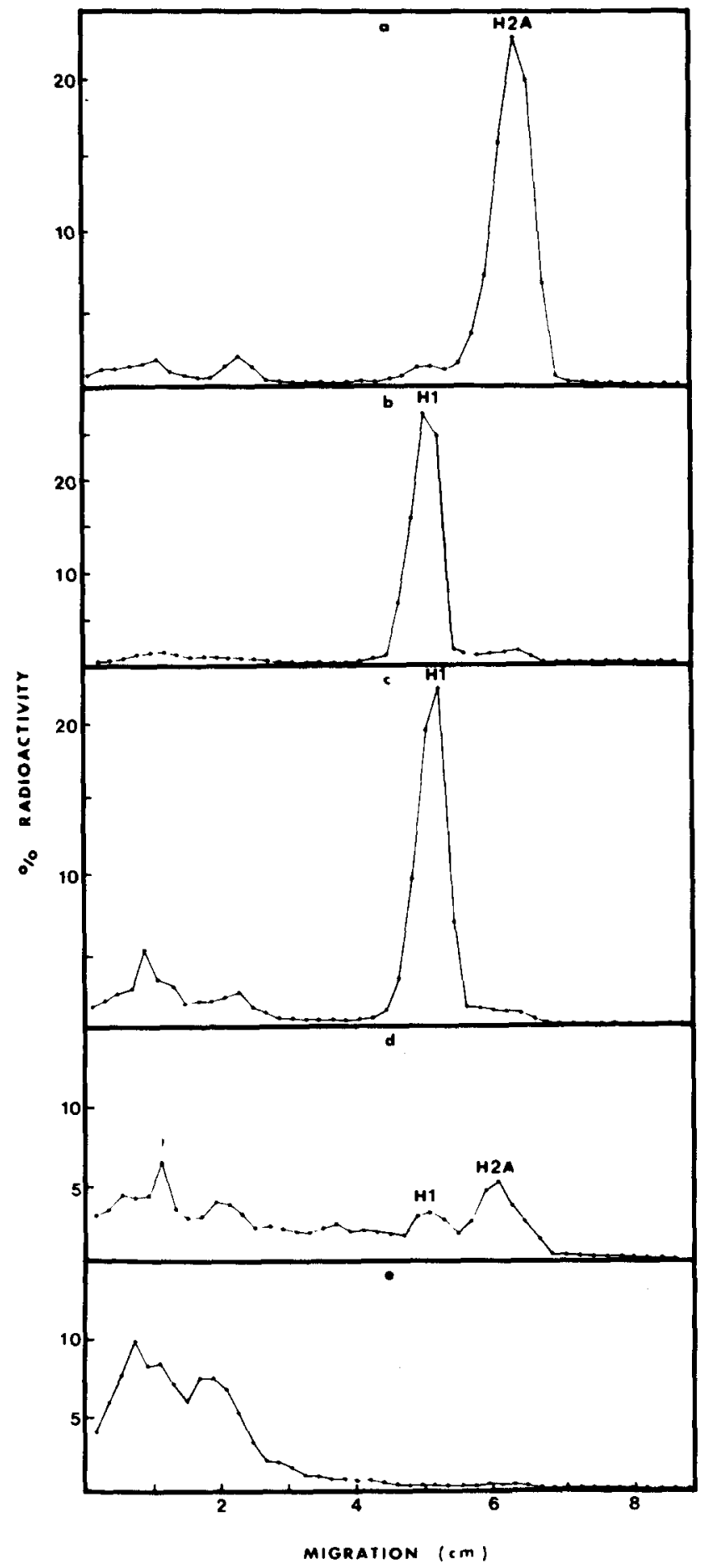

Fig. 8. Distribution of ${ }^{32} \mathrm{P}$ in histones phosphorylated by kinase fractions extracted from early $S$ phase cells. Histones alone were used as substrate and were analysed by acetic acid/urea polyacrylamide gel electrophoresis as described in Materials and Methods. Proteins phosphorylated by kinase fractions: (a) I; (b) II; (c) III; (d) IV; (e) V. 
I-IV all phosphorylated histones. This result suggested that these kinase fractions could phosphorylate both histones and non-histone proteins. Therefore, either the presence of non-histone proteins inhibited histone phosphorylation by kinase fractions I and IV, or these kinases preferentially phosphorylated non-histone chromosomal proteins in the presence of histones. The kinase fractions were specific for the type of histone which they phosphorylated: fractions II and III phosphorylated only histone $\mathrm{H} 1$; fraction I, H2A; and fraction IV both $\mathrm{H} 1$ and $\mathrm{H} 2 \mathrm{~A}$. The last case could be due either to a single kinase that had the ability to use both histones $\mathrm{H} 1$ and $\mathrm{H} 2 \mathrm{~A}$ as substrate, or more probably, to two kinases with different substrate specificities.

It is extremely unlikely that any of the radioactive phosphate was incorporated into nucleic acids or lipids because (i) both enzymes and substrates contained little if any nucleic acids or lipids, and (ii) $\left[\gamma{ }^{32} \mathrm{P}\right] \mathrm{ATP}$ was used as a precursor. However, to eliminate the possibility that some nucleic acid may have been labelled and remained attached to protein in the gels, a gel was incubated in $5 \%$ trichloroacetic acid for $30 \mathrm{~min}$ at $90^{\circ} \mathrm{C}$ before slicing [35]. This hot acid treatment hydrolyses nucleic acids but not proteins. There was no difference in the extent and distribution of radioactivity in acid and non-acidtreated gels, suggesting that the radioactivity was incorporated into protein and not nucleic acid.

\section{Discussion}

We have studied the activities of nuclear protein kinases during the cell cycle of synchronised $\mathrm{HeLa} \mathrm{S}_{3}$ cells. Cell cycle stage-specific fluctuations were observed in the activities of total nuclear protein kinases and nuclear protein kinase fractions.

In our experiments, homologous HeLa cell chromosomal proteins served as substrates for in vitro phosphorylation by nuclear protein kinases; a subset of these substrates were non-histone chromosomal proteins enriched in phosphoserine and phosphothreonine residues. The rationale for utilising homologous nuclear proteins as substrates was several fold. (1) Because phosphorylation of non-histone chromosomal proteins has been implicated in modifying the structural and/or transcriptional properties of the eukaryotic genome, kinases responsible for such phosphorylation may possess specificity for certain chromosomal proteins or for particular sequences of amino acids surrounding the site of phosphorylation. Such sequences may be lacking in an unnatural substrate. Within this context Busch's group [36] has recently shown that the phosphorylation sites of some non-histone chromosomal proteins are flanked by long stretches of acidic amino acids. (2) Previous results [20] have shown that some nuclear kinase fractions do not phosphorylate histones or heterologous substrates, such as casein or phosvitin. Conversely, other kinases with limited activity toward their natural substrates may indiscriminately phosphorylate phosvitin or casein.

Since the non-histone chromosomal phosphoprotein fraction that was utilised as substrate for nuclear protein kinase-mediated phosphorylation was the same as that from which the nuclear protein kinases were derived, endogenous kinase activity in the substrates was heat inactivated. A high substrate : 
enzyme ratio (at least $5: 1$ ) was maintained when activities of nuclear protein kinase fractions were assayed so that the proteins associated with the enzyme fractions did not make a significant contribution to the available substrate.

The increase in unfractionated nuclear protein kinase activity we observed during $\mathbf{S}$ phase in HeLa $\mathbf{S}_{3}$ cells is greater than the concomitant increase in the amount of homologous protein substrate. These data suggest that the increase in the enzyme activity is not merely in response to the increase in level of substrate, but that it may more significantly be related to biological functions taking place during the cell cycle. In contrast, Costa et al. [23] found that in CHO cells, cell cycle-specific variations in nuclear protein kinase activity are accompanied by comparable fluctuations in the level of substrate. However, they used exogenous casein as a substrate and hence their results may not accurately reflect enzyme activities toward homologous substrates.

The cell cycle stage-specific fluctuations we observed in the in vitro phosphorylating activities of unfractionated nuclear protein kinases correspond closely to the variations in the in vivo phosphorylation of non-histone proteins during the cell cycle [14]. The increase in total unfractionated nuclear protein kinase activity during late $S$ and $G_{2}$ did not coincide with either DNA and histone synthesis or mitosis, but occurred between these two periods of the cell cycle. Thus, the possibility arises that non-histone protein kinases may play a role in modifying (by phosphorylation) non-histone chromosomal proteins involved in the packaging and/or repression of newly synthesized DNA prior to mitosis. Such non-histone chromosomal proteins may be synthesized and concomitantly phosphorylated during the $S / G_{2}$ phase transition or they may be present throughout the cell cycle (as components of chromatin, in the nucleoplasm or in the cytoplasm) and be selectively phosphorylated at this time. The decrease of nuclear protein kinase activity during mitosis corresponds to the low level of phosphorylation of non-histone chromosomal proteins observed at this stage of the cell cycle and can be correlated with the suppression of in vitro and in vivo RNA synthesis during this period [37-41]. The increase in kinase activity we observed during the transition from mitosis to $G_{1}$ corresponds to the increase in non-histone chromosomal protein phosphorylation that occurs during this stage of the cell cycle [14] and may play a role in the activation or depression of the genome following mitosis. However, functional biological relationships cannot be established by correlative evidence alone and the possibility must be considered that the variations in kinase activity that we observed are not associated with chromatin condensation or activation but rather with some other cell cycle stage-specific biological function.

Five reproducible fractions containing nuclear protein kinase activity were obtained from the complex and heterogeneous nuclear phosphoproteins and the activities of these fractions were examined throughout the cell cycle. As reported previously [24], each of the five fractions exhibited variations in levels of enzyme activity, optimal $\mathrm{pH}$, metal requirements and substrate specificity. However, it should be emphasised that the individual fractions do not contain purified kinases. Each kinase fraction contains proteins that do not exhibit enzyme activity and it is reasonable to anticipate that more than a single species of nuclear protein kinase may be present in each fraction.

The in vitro phosphorylation of nuclear proteins mediated by unfractionated 
kinases extracted from $\mathrm{G}_{1}, \mathrm{~S}, \mathrm{G}_{2}$ and mitotic HeLa cells suggests that some nonhistone chromosomal proteins are phosphorylated throughout the cell cycle, whereas others are phosphorylated only during certain stages, and during any particular stage of the cell cycle, some proteins are phosphorylated by all or most of the kinase fractions whereas others are phosphorylated only be specific fractions. This cell cycle stage-specific phosphorylation of non-histone chromosomal proteins by isolated kinases agrees with previous reports of the selective phosphorylation of particular proteins during specific stages of the cell cycle in intact cells [14]. Taken together, the in vitro and in vivo observations suggest that the phosphorylation of particular non-histone chromosomal proteins may be involved in cell cycle stage-specific nuclear functions, structural and/or regulatory. The variations in kinase activity during the cell cycle could be due to (i) a constant complement of kinases that are associated with chromatin throughout the cell cycle but whose activity and specificity are altered, possibly due to interactions with effectors (which could include other non-histone chromosomal proteins); (ii) certain kinases that are present in the nucleoplasm but only become attached to the chromatin during certain stages of the cell cycle; (iii) a translocation of a kinase from the cytoplasm to the chromatin $[42,43]$; (iv) cell cycle stage-specific synthesis of kinases; (v) the synthesis of nuclear protein kinases or components thereof when the enzymes are required. Further fractionation of the nuclear protein kinases and assessments of activity should permit us to differentiate between these alternatives.

The addition of histones to the assay medium produced different cell cycle stage-specific effects on the activitivities of the various kinase fractions. The greatest effects of histones occurred with kinases from $G_{1}$ (which exhibited decreased activity in the presence of histones) and from mitosis (which exhibited increased activity in the presence of histones). These two stages correspond, respectively, to the times of least and greatest phosphorylation of histones during the cell cycle.

When a mixture of histones and non-histones was used as substrate, only kinase fraction II phosphorylated histones throughout the cell cycle, but most of the fractions from $G_{1}$ phase cells phosphorylated histones. This suggests some cell cycle specificity of the histone kinases, as found by Hardie et al. [44], and this would correspond to the cell cycle-specific phosphorylation of histones in vivo [45-49]. Associated with the histone phosphorylation there is a preferential decrease in the phosphorylation of some non-histone chromosomal proteins. This may be due either to the presence of a kinase that can phosphorylate non-histone proteins but has a preference for histone as a substrate, or to a histone-mediated inhibition of the phosphorylation of a particular non-histone protein [34]. In some cases the presence of histones seems to stimulate the phosphorylation of specific classes of non-histone proteins. Evidence for the histone-stimulated phosphorylation of non-histone chromosomal proteins has been reported previously [33,34].

Our data do not suggest a functional relationship between DNA replication and the modifications in protein kinase activity observed during the $S$ phase of the cell cycle. When we compared the activities of unfractionated nuclear protein kinases or the five kinase fractions from $\mathrm{S}$ phase HeLa cells with the activities of kinases from $\mathbf{S}$ phase cells treated with cytosine arabinoside, signifi- 
cant differences were not observed. These results are consistent with the inability of DNA synthesis inhibitors (cytosine arabinoside and hydroxyurea) to modify non-histone chromosomal protein phosphorylation in intact HeLa cells (Pumo et al., unpublished observations). However, the possibility should not be dismissed that non-histone protein kinases may play a role in phosphorylating non-histone chromosomal proteins involved in the repression and/or condensation of newly synthesised DNA.

We want to emphasise that there are many problems associated with trying to use results obtained in vitro to explain processes that occur in vivo. For example, in this system the extraction of the kinases may have left behind molecules that are involved in the control of these enzymes in vivo. However, loss of specific non-histone chromosomal protein kinases during the separation of phosphoproteins into five components seems unlikely since the pattern of in vitro phosphorylation mediated by the five nuclear protein kinase fractions collectively is quantitatively and qualitatively similar to that mediated by the unfractionated preparations. Another problem is that during the extraction procedure the native structure of the chromatin may be altered and consequently the enzyme and substrate molecules presumably no longer have the spatial constraints that may exist in vivo. Yet another problem is the possibility of non-specific aggregation taking place in vitro. However, despite these difficulties we feel that the information obtained through the use of the enzymes in vitro will contribute to our understanding of the protein phosphorylation processes associated with chromatin, and hence to elucidation of the role of these proteins in chromosomal functions.

\section{Acknowledgements}

We thank Dr. Judith Thomson for discussion, Jeudi Davis and Linda Green for growing the cells, and Carlyn Ebert for typing the manuscript. These studies were supported by Grant PCM 77-15947 from the National Science Foundation.

\section{References}

1 Stellwagen, R.H. and Cole, R.D. (1969) Annu. Rev. Biochem. 38, 951-990

2 Spelsberg, T.C., Wilhelm, J.A. and Hnilica, L.S. (1972) Subcell. Biochem. 1, 107-145

3 Cameron, I.L. and Jeter, J.R., Jr. (eds.) (1974) Acidic Proteins of the Nucleus, Academic Press, New York

4 Elgin, S.C.R. and Weintraub, H. (1975) Annu. Rev. Biochem. 44, 725-774

5 Stein, G.S., Spelsberg, T.C. and Kleinsmith, L.J. (1974) Science 183, 817-824

6 Stein, G.S. and Kleinsmith, L.J. (eds.) (1975) Chromosomal Proteins and Their Role in the Regulation of Gene Expression, Academic Press, New York

7 MacGillivray, A.J. and Rickwood, D. (1974) in Biochemistry of Differentiation (Paul, J., ed.), pp. 301-361, Butterworth, London

8 Stein, G.S., Stein, J.L. and Thomson, J.A. (1978) Cancer Res. 38, 1181-1 201

9 Phillips, I.R.. Shephard, E.A., Stein, J.L. and Stein, G.S. (1980) in Eukaryotic Gene Regulation (Kolodny, G., ed.), CRC Press, West Palm Beach, in the press

10 Busch, H. (ed.) (1978-1979) The Cell Nucleus, Vols. 4-7, Academic Press, New York

11 Kleinsmith, L.J. (1975) J. Cell Physiol. 85, 459-476

12 Kleinsmith, L.J., Stein, J. and Stein, G. (1976) Proc. Natl. Acad. Sci. U.S. 73, 1174-1178

13 Thomson, J.A., Stein, J.L., Kleinsmith, L.J. and Stein, G.S. (1976) Science 194, 428-431

14 Platz, R.D., Stein, G.S. and Kleinsmith, L.J. (1973) Biochem. Biophys. Res. Commun. 51, $735-740$ 
15 Bhorjee, J, and Pederson, T. (1973) Biochemistry 12, 2766--2773

16 Karn, J., Johnson, E.M., Vidali, G. and Allfrey, V.G. (1974) J. Biol. Chem. 249, 667-677

17 Stein, G.S. and Borun, T.W. (1972) J. Cell Biol. 52, 292-307

18 Borun, T.W. and Stein, G.S. (1972) J. Cell Biol. 52, 308-315

19 Gerner, E.W. and Humphrey, R.M. (1973) Biochim. Biophys. Acta 331, 117-127

20 Kish, V.M. and Kleinsmith, L.J. (1974) J. Biol. Chem. 249, 750-760

21 Thomson, J.A., Chiu, J.-F. and Hnilica, L.S. (1975) Biochim. Biophys. Acta 407, 114-119

22 Farron-Furstenthal, F. and Lightholder, J.R. (1976) in Onco-Developmental Gene Expression (Fishman, W.H. and Sell, S., eds.), pp. 57-64, Academic Press, New York

23 Costa, M., Fuller, D.J.M., Russell, D.H. and Gerner, E.W. (1977) Biochim. Biophys. Acta 479, 416426

24 Thomson, J.A., Mon, M.J., Stein, J.L., DuVal, K.A., Kleinsmith, L.J. and Stein, G.S. (1979) Cell Differ. 8, 305-321

25 Farron-Furstenthal, F. and Lightholder, J.R. (1977) FEBS Lett. 84, 313-316

26 Mallette, L.E., Neblett, M., Exton, J.H. and Langan, T.A. (1973) J. Biol. Chem. 248, 6289-6291

27 Sarma, M.H., Feman, E.R. and Baglioni, C. (1976) Biochim. Biophys. Acta 418, 29-38

28 Glynn, I.M. and Chappell, J.B. (1964) Biochem. J. 90, 147-149

29 Layne, E. (1957) Methods Enzymol. 3, 447-454

30 Laemmli, U. (1970) Nature 227, 680-685

31 Panyim, S. and Chalkley, R. (1969) Biochemistry 8, 3972-3979

32 Stein, G., Stein, J., Shephard, E., Park, W. and Phillips, I. (1977) Biochem. Biophys. Res. Commun. $77,245-252$

33 Kaplowitz, P.B., Platz, R.D. and Kleinsmith, L.J. (1971) Biochim. Biophys. Acta 229, $739-748$

34 Johnson, E.M., Vidali, G., Littau, V.C. and Allfrey, V.G. (1973) J. Biol. Chem. 248, 7595-7600

35 Bhorjee, J.S. and Pederson, T. (1976) Anal. Biochem. 71, 393-404

36 Mamrack, M.D., Olsen, M.O.J. and Busch, H. (1978) Fed. Proc. 37, 1786

37 Taylor, J.H. (1960) Ann. N.Y. Acad. Sci. 90, 409-421

38 Prescott, D.M. and Bender, M.A. (1962) Exp. Cell Res. 26, 260-268

39 Baserga, R. (1962) J. Cell Biol. 12,633-637

40 Johnson, T.C. and Hollard, J.J. (1965) J. Cell Biol. 27, 565-574

41 Stein, G.S. and Farber, J.L. (1972) Proc. Natl. Acad. Sci. U.S. 69, 2918-2921

42 Jungmann, R.A., Lee, S.-G. and DeAngelo, A.B. (1975) in Advances in Cyclic Nucleotide Research (Drummond, G.1., Greengard, P. and Robison, G.A., eds.), Vol. 5, pp. 281-306, Raven Press, New York

43 Jungmann, R.A. and Kranias, E.G. (1977) Int. J. Biochem. 8, 819-830

44 Hardie, D.G., Matthews, H.R. and Bradbury, E.M. (1976) Eur. J. Biochem. 66, $37-42$

45 Marks, D.B., Paik, W.K. and Borun, T.W. (1973) J. Biol. Chem. 248, 5660-5667

46 Bradbury, E.M., Inglis, R.J., Matthews, H.R. and Sarner, N. (1973) Eur. J. Biochem. 33, 131-139

47 Gurley, L.R., Walters, R.A. and Tobey, R.A. (1975) J. Biol. Chem. 250, 3936-3944

48 Hohmann, P., Tobey, R.A. and Gurley, L.R. (1976) J. Biol. Chem. 251, 3685-3692

49 Hohmann, P. (1978) Subcell. Biochem. 5, 87-127 